\title{
Phosphate Content of Mudbanks along the Malabar Coast
}

THE importance of the phosphate content of water masses as a limiting factor in their organic produetivity has long been recognized. The investigations of Mortimer ${ }^{1}$, Moore ${ }^{2}$, Stephenson ${ }^{3}$ and Rochford ${ }^{4}$ have stressed the importance of the bottom muds in the phosphate cycle.

The inshore sea along the Malabar coast of India has a peculiar environment owing to the formation of extensive banks of very fine mud settling regularly after the rough weather of the south-west monsoon which occurs from the month of June to the beginning of September. The area is also subject to a heavy rainfall (121 in. per annum at Calieut) most of which occurs during these months. This region of the Indian coast is highly productive in respect of fisheries and shows a marked seasonal cycle in its biological features, this being apparently closely related to the south-west monsoon.

In connexion with the study of the fishery and ecology of the inshore area near Calicut, it was considered useful to study the composition of the material forming these mudbanks and to follow the seasonal changes, especially in its phosphate content in relation to the phosphate content of the overlying water and to the seasonal changes in the biology of the area. In view of recent trends in such phosphate studies, it was particularly suggested to me by Dr. N. K. Panikkar that the west coast mudbanks probably form reservoirs of inorganic nutriment playing an important part in the annual cycle, and that their detailed investigation is necessary to understand the fisheries cycles. Work on these lines is in progress, and it is already apparent that these mudbanks contain considerable quantities of phosphates (even if we take only the interstitial inorganic fraction into account) and that the results confirm the above view. The work has also shown that the release of phosphates from the mudbanks takes place largely during the south-west monsoon period, when the waters are continually highly agitated by the strong winds.

The accompanying table shows the values of interstitial and adsorbed phosphates of mud samples taken at two stations near Calicut during the months of January-June 1952. The procedure followed in these estimations was that detailed by Rochford ${ }^{4}$ with slight modifications. The mud samples were taken by means of a grab sampler instead of a core sampler.

The individual values of the interstitial phosphate (per gm. of mud) were themselves often higher than the corresponding values of inorganic phosphate (per litre) in the overlying water during the pre-monsoon months, and per unit weight or volume the mud may be said to contain several hundred times as much phosphate as the water-layer above it. The interstitial phosphate is released into the water by agitation. A severe agitation of the sea bottom, noticed during the south-west monsoon of 1950 , resulted in a large increase in the phosphate content of the wator. During 
[NTerstitial Phosphate as Phosphate Phosphords in Parts per Mmion of Dry Med aNd Adsorbed Phosphate Similarly iN Dry Silt

\begin{tabular}{|c|c|c|c|c|c|c|c|c|c|}
\hline \multirow{3}{*}{ Months } & \multirow{3}{*}{$\begin{array}{c}\text { Samples } \\
\text { per } \\
\text { station }\end{array}$} & \multicolumn{4}{|c|}{ Station I ( $4 \mathrm{~m})}$. & \multicolumn{4}{|c|}{ Station II ( $19 \mathrm{~m})}$. \\
\hline & & \multicolumn{2}{|c|}{ interstitial } & \multicolumn{2}{|c|}{ Adsorbed } & \multicolumn{2}{|c|}{ Interstitial } & \multicolumn{2}{|c|}{ Adsorbed } \\
\hline & & Range & Jiean & Range & Mean & kange & Jean & Range & Mean \\
\hline $\begin{array}{l}\text { January } \\
\text { February } \\
\text { Mareh } \\
\text { April } \\
\text { May } \\
\text { June }\end{array}$ & $\begin{array}{l}5 \\
4 \\
3 \\
4 \\
3 \\
2 \\
2\end{array}$ & $\begin{array}{r}13 \text { to } 35 \\
22 \text { to } 43 \\
19 \text { to } 27 \\
11 \text { to } 25 \\
13 \text { to } 19 \\
7 \text { to } 20\end{array}$ & $\begin{array}{l}26 \\
35 \\
23 \\
17 \\
15 \\
13\end{array}$ & $\begin{array}{r}19 \text { to } 80 \\
9 \text { to } 41 \\
13 \text { to } 43 \\
17 \text { to } 28 \\
20 \text { to } 35 \\
22 \text { to } 25\end{array}$ & $\begin{array}{l}47 \\
21 \\
25 \\
24 \\
27 \\
23\end{array}$ & $\begin{array}{c}21 \text { to } 27 \\
25 \text { to } 33 \\
17 \text { to } 25 \\
12 \text { to } 19 \\
\mathbf{2 4} \text { to } 46 \\
9\end{array}$ & $\begin{array}{l}25 \\
29 \\
20 \\
15 \\
33 \\
9\end{array}$ & $\begin{array}{r}18 \text { to } 68 \\
9 \text { to } 22 \\
16 \text { to } 39 \\
9 \text { to } 33 \\
12 \text { to } 17 \\
4 \text { to } 16\end{array}$ & $\begin{array}{l}33 \\
16 \\
24 \\
18 \\
14 \\
10\end{array}$ \\
\hline
\end{tabular}

the pre-monsoon months in 1952 again, the phosphate content of the inshore water was very low, but it increased after the commencement of the monsoon rough weather that disturbed the mudbanks. It appears highly probable that the well-marked seasonal features in the biology of the inshore area along this coast are closely related among other factors to the existence of these extensive mudbanks, the retention by them of relatively large quantities of phosphates (and perhaps other nutrients) and the release of these during the south-west monsoon every year.

The mudbanks have also been found to contain fairly high quantities of adsorbed phosphate. The material of these mudbanks is derived partly from the laterite formation which fringes this coast ${ }^{5}$. An analysis of a sample of laterite has revealed a high 'adsorbed' phosphate content, and since a considerable quantity of laterite silt is washed into the sea during the rainy seasons, this seems to be a constant source to supplement the local turnover of phosphates in the inshore area.

I wish to thank Dr. N. K. Panikkar, Dr. W. R. G. Atkins and Dr. B. S. Bhimachar for helpful criticism.

Central Marine Fisheries Research Sub-Station,

$$
\text { G. SeShapPa }
$$

West Hill,

Calicut, India.

Aug. 30.

13ortimer, G. H., J. Ecol., 29, 280 (1941); 30, 147 (1942).

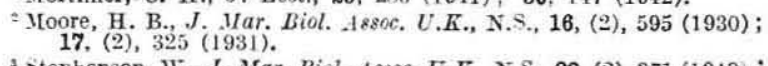

s Stephenson, W., J.Mar. Biol. Assoc. U.K., N.S., 28, (2), 371 (1949); Proc. Indo-Pacific Fish. Coun., 2nd Mleeting 1950, 184 (1951).

4 Kochford, D. J., Proc. Indo-Pacific Fish. Coun., - nd Meeting 1950, 157 (1951).; Aust. J. Mar. Freshuater Res., 2, (1), 1 (1951).

s Bristow, R. C." "History of Mudbanks" (Cochin Govt. Press, 193s). Du Cane, ¿. G., Bristow, R. C.. Coggin Brown, C.. and Keen; B. A., Report of the Special Committee on the Movement of Mudbanks, Cochin (1938). 